\title{
Threats to Security in Nigeria
}

\author{
Arinze Ngwube \\ Federal University Oye_Ekiti \\ Ekiti State Nigeria \\ E-mail: Arinze.ngwube@fuoye.edu.ng
}

\begin{abstract}
Nigerians expect that leadership should guarantee the security of the populace who in return will be law abiding. The reverse is the case with Nigeria. Each time one reads the newspapers, they speak of one crisis or the other in the country. This is a source of concern among scholars. It is becoming worrisome that people sleep with one eye closed. The reason is that state institutions and agencies are not effective and efficient. Leadership has failed to address these threats leaving the people on their own. The country has not been able to fulfil its potentials due to the existence of threats in the polity. This has given Nigeria a bad name. Investors are cautious of coming to a country where their lives and investments are not safe.Beside; Nigeria has been on a steady decline in the Global peace index. Out of 158 countries surveyed, the country was $117^{\text {th }}$ in $2007,129^{\text {th }}$ in 2008 and 2009,137 ${ }^{\text {th }}$ in $2010,142^{\text {nd }}$ in 2011 and $146^{\text {th }}$ in 2012. Even a country like Chad is more peaceful than Nigeria. It remains the duty of government to provide an enabling environment for the populace to fulfill her potential and the absence of this pose a threat in the polity of the country. This work is linked to sustainstable development and sustainability. The absence of security leads to political and economic instability. The absence Using observation methods and secondary sources, the paper examined the threats to security in Nigeria.
\end{abstract}

Keywords: Kidnapping, corruption, poverty, oil bunkering, electoral violence,Boko Haram

\section{Introduction}

There is political uncertainty and turbulence in Nigeria which pose serious concerns for the citizens and noncitizens. There is no doubt that these are tumultuous times in the country as many residents face economic, political and social problems. President Goodluck admits that the security of the country is worrisome because of the kidnapping problem in recent years. Nigerians believe that the state institutions and agencies are failing in their roles. The reason for this is that of selfish purposes. It is sad that after 52 years of independence, the Nigerian State cannot protect the lives and property of the citizens of the country. Nigerians are asking themselves the question of how long it will take the different levels of government to put into place corrective actions to eradicate the problems associated with lawlessness. They have no confidence in the government of the day. One has observed the proliferation of AK47 riffles, submachine guns and other sophisticated weapons in the country due to the people's readiness for self defence. These arsenals pose grave danger if they get into the wrong hands.

This paper is divided into three parts. The first section conceptualises the term threats and security; the second section addresses the threat to security in Nigeria; the final section summarizes the paper.

\section{Conceptual Clarifications}

Threats are risks to society. In legal terms, a threat represents communicated intent to inflict harm or damage to a person or property to force someone's compliance or to restrict his or her freedom. In this case, one is concerned with threats to security; these actions or inactions pose risks to the unity of the country .Threats are related to security issues. To understand Security, one must be able to evaluate the prevailing threat situation. And this depends on the values and interests of the nation as they are of threat perceptions. Threat situations are also dynamic and in 
many cases highly politically determined (Ochoche, 1997:11). Multiple threats that defy military solutions have driven scholars to challenge conventional notions of security, and to redefine the concept so that it encompasses not only freedom from physical violence, but also material well being of individuals and the environmental health of the planetary system (Dokubo, 2010:139). Security as a concept has been a subject of broad and rich debate due to its multi-dimensional nature. For years, the history of mankind was interspersed by the frenzied search for the best way of ensuring the security of people, their property their territories their states, their institutions etc. For Imobighe, Security has to do with freedom from danger or from threats to a nation's ability to protect and develop itself, promote its cherished values and legitimate interests (Imobighe 1990: 224).

Stephen Walt (1992) however, emphasise a very narrow view of security .To the question of what is security? Waltz answers that: "it is the phenomena of war, the threat of use and the control of military force". Balogun (2003:1) observed at a forum that "man's primary and engaging concern has been that of survival and protection; from the vagaries of nature, natural disasters and from the ill-intentions and misdeeds of his fellow men". This is amplified by section 14(b) of the Nigeria constitution (1999), which states inter alia that:-"The security and welfare of the people shall be the primary purpose of government". A secure nation is one that is able to protect and develop itself so that it can develop its core values, meet the needs of its people, and provide them with the right atmosphere for self improvement". OBC Nwolise (1988) posits that:- security refers to safety, freedom from danger or risk. Arnold Wolfers (1962) defines security as follows: security in an objective sense is the absence of threats to acquired values, in a subjective sense the absence of fear that such values will be attack may involve it. Robert McNamara (1968) posits that: "in a modernizing society security means development; security is not military force, though it may include it. Security is development and without development there can be no security". It is being understood that security also concerns the individual and groups and not just states alone. When individuals are not secured, then the states cannot be secure. The testimony to this is the rise of non military sources of threats to security at the individual, societal, state regional and global levels. This has led to the broadening of the concept of security to include non-military dimensions such as social, economic, and political factors now poverty, human rights, political disputes, political succession, bad governance etc also constitute issues affecting peace and security. National security is the 'readiness and capability of a country to contain internal and external threats to its existence and well-being (the military dimension), and ensure the socio-economic welfare of its peoples (the developmental dimension)' (Tyoden 2005:173). The new emphasis on an expanded definition of national security does not suggest that the idea is a new one, but rather that its relevance was greatly undermined by security doctrines and strategic considerations that shaped the idea of security during the Cold War era.

Within the context of this paper, national security refers to the capacity of a state to promote the pursuit and realization of the fundamental needs and vital interests of man and society, and to protect them from threats which may be economic, social, environmental, political, military or epidemiological in nature. In this sense, it has both qualitative and dynamic dimensions. Qualitatively, it encapsulates the unending drive of the state for improving the safety of, and protecting the lives, property and resources within its defined territorial boundaries. It is dynamic 
in the sense that its broad contours oscillate with emergence of new threats or the transformation of old threats, which may come from within or outside its environment (Onuoha 2007:4). Therefore threats to national security are not static, but dynamic, and just as the political, economic, military and social causes of threats change, so does the national security posture of a country change (Okodolor 2004:211). In the context of Nigeria's national security considerations, Former President Olusegun Obasanjo contends that:

The primary objective of national security shall be to strengthen the Federal Republic of Nigeria, to advance her interest and objectives to contain instability, control crime, eliminate corruption, enhance genuine development, progress and growth, and improve the welfare and well-being and quality of life of every citizen (Tyoden 2005:172-173).

In this sense, national security is a collection of two broad crucial elements: state security and human security. It entails the preservation of the safety of Nigerians at home and abroad and the protection of the sovereignty of the country and the integrity of its assets (Federal Republic of Nigeria 2006:2). Thus a country is secured to the extent that the political leadership is able to anticipate, recognize and respond effectively to these threats, using the available national resources to ensure the safety of life and property of the citizens, and guarantee the integrity of its territorial boundaries as well as its strategic assets, both within and outside its territory. One thing that confronts Nigeria today is the resurgence of civil unrest and its threat to her security. From the Niger Delta, to the northern part of Nigeria, no one is in doubt that the country is on fire. This has deepened threats to security among the majority of Nigerians, particularly those who live in parts of the country other than what they regard as their own. The green lights are on if care is not taken could lead to a civil war. The situation has compelled some Nigerians to possess firearms and ammunitions. This has resulted to the increase of Ak47 rifles, submachine guns and other sophisticated weapons in the country might be due to the people's readiness for self defence. Despite several committees being set up none has been able to identify the root causes, leading to the administration of wrong remedies. Matters are not even helped by the increasing inability of the Nigeria state to address the security threat. This has portrayed Nigeria as one of the most unsecure place to live in the world today. This has scared foreign investors who have left in haste to neighbouring countries and her citizens are leaving the country on a daily basis. People are beginning to question the capability of government in addressing its security challenges in the $21^{\text {st }}$ century. Whenever the word security threat is mentioned, the immediate feeling that gets to one's mind is the state of being subject to danger which is what many feel and experience in Nigeria. To so many foreign countries, Nigeria is being described as one of the most dangerous places in the world filled with so much corruption which stinks. Various sources of threat may include political, military, cultural, economic and health security from local and regional areas to the national globe.

\section{Threats to Security}

\section{Poverty}

Poverty according to Herbert J. Gans, survives in part because it provides a baseline of failure which tends to reassure the non-poor of their worth; something akin to "a reliable and relatively 
permanent measuring rod for status comparison". Any contrary impression has the potential to turn aside attention from the larger socio-economic structure on which poverty is entrenched. Indeed, poverty as a subject has assumed global dimension that has suddenly become conditional for debtor nations to prepare and of course foster what is now called Poverty Reduction Strategy Paper (PRSP) to earn any form of attention from the world financial institutions. Therefore, poverty, not just as an incident but as a process in social relation forms, has been extended in reach and impact and so giving hint of a far more devastating effect on the environment than it down-graded the individual life of the immediate victim. In other words, the very bold angles of poverty, as now established, have opened new world knowledge of it as sources of far more diffuse impact than the despair of it on the one man who has failed to provide for his family. To appreciate this development in its fuller form, it will be gainful to consider the views of Adeline Caenonis on the trends and patterns of poverty as they manifested, differently, in rural and urban areas. An overview presentation represents the segmentations as the overlap of social classifications, which bursts down the relatively well to do in the rural areas as presenting a true description of the definitively poor in the urban areas. Conversely, the active player in the urban area who may have attained a stable urban economic life but gets suddenly transported to the rural area, will be reduced to the deprived and poor status, if prosperity is measured in terms of both possession of such definite property as land and access to the social stabilizing institutions as roles in decision making bodies and specialized societies.

In other words, he who may have attained some stability in the urban area - marked out by certain possessions - but who cannot even transfer such acquisitions to the rural areas - that is if such would make any meaning there - may have to be forced to accept severe social downgrading if he finds himself back in the native land. In a straight form, it is being said that poverty can be geographically determined while wealth has social meanings, which will never be the same everywhere we go. But riding a global overview, particularly on the crest of sociological researches driven by Elizabeth Wilkins, poverty is termed "the income of $a$ community which in subdivision among families and kindred, is less than 40 per cent of the norm which manifests more in poor infrastructure, poor health, poor nutrition, poor self esteem, low hygienic standards, low intellectual development and lack of capacity to articulate social, economic and political environment and low per capita income”.

The most pathetic feature of the Nigerian society today is that an elite minority of its citizens are living in affluence, while the majority is wallowing in poverty. These skewed economic relations do not reflect the geographical spread of resource endowment. It is rather a product of greed, injustice and selfishness. This is beyond any economic principle that poverty has no geographical boundary. Speaking at the 2011 May Day lecture, the former Minister of National Planning and Finance, Dr Shamsuddeen Usman said that Nigeria had achieved a reasonable growth rate since 1999 with no significant effect on poverty or unemployment Ironically the minister said that between 1999 and 2009, GDP increased from $\$ 36$ billion to $\$ 250$ billion while the number of unemployed people increased from 5.9 million to 17.5 million. How can there be national economic growth with increased national poverty? When people have no jobs they are deprived of the capacity to earn steady real income and cannot live a socially productive existence. The high level of poverty in Nigeria is exacerbating the problem of violent crimes. Many engage in crime as a result of extreme poverty and desperation. Millions of our citizens are without shelter 
and are not able to feed. These hungry and impoverished persons are ready tools in the hands of criminal masterminds or easily join criminal gangs in order to survive.

\section{Election Violence}

Election is the method through which citizens choose their representatives. Its centrality to democratic governance can therefore not be overemphasized. In current times, the relationship between free, fair and credible elections and good governance is so strong that any attempt to undermine the process often invokes the wrath of the people. You will recall that part of the political upheavals we are witness in North Africa, the Middle East and some Gulf States are noticeable to the failure of the people to freely choose their leaders. Electoral violence commonly refers to violence that is directly or indirectly connected to protest against an election. Nigeria's post independence history is stuffed with accounts of incidents of electoral violence.

The violence that took place during 1964-65 elections in the then Western Region (popularly referred to as the "wild, wild west") which found expression in "operation wetie" is illustrative of the danger associated with electoral violence especially the one that culminated in the first Military intervention in Nigeria. It will be recalled that subsequent elections in Nigeria's democratic experience were also been marred by pockets of electoral violence. It is important to mention that the degree of electoral violence seem to have scaled down drastically as Nigeria continues her journey to nationhood. The post electoral violence that characterized the 2011 Presidential Election has clearly shows the challenges of violence in our polity .It portray the whole country as a whole, in bad light. What is responsible for these are greed, selfishness and desire to win by all means? This is a serious security threat and will continue for a long time unless Nigeria learns to accept the wish of the people.

\section{Boko Haram}

Boko Haram, means "Western education is sinful" in Hausa, was established in 2002 in Maiduguri, the capital of Nigeria's Borno State. It has since spread to other northern and central Nigerian states. The group officially is known as Jama'atu Ahlis Sunna Lidda'awati wal-Jihad, Arabic for "group committed to propagating the Prophet's teachings and jihad." Individuals in the country have referred to Boko Haram as Nigerian's Taliban in reference to the group's call for Shariah throughout Nigeria. Indeed, Boko Haram has been involved since its inception in several outbursts of inter-communal violence, including the November 2008 violence in which 800 people lost their lives in Jos. The July 2009 violence, which brought Boko Haram to the world's attention, Boko Haram founder Mohammed Yusuf and his deputy, Abubakar Shekau, were both killed. Yusuf died in police custody during an escape attempt; however his followers have called his death an extrajudicial execution. Since the destruction of Boko Haram's leadership, the exact structure and makeup of the group has been unclear. Boko Haram now seems to lack organizational structure or strong leadership. If the group has any central leadership, it has maintained a very low profile since Yusuf's killing. It may even be in hiding, possibly in a neighboring country. Mixed messages have emerged from various individuals claiming to speak for Boko Haram. Some figures have come across as more moderate and willing to negotiate, while others have been more strident, rejecting talks. This difference makes 
it appear that Boko Haram comprises a loose confederation of militants operating relatively independently from one another, rather than a cohesive, hierarchical organization pursuing a unified set of objectives. Boko Haram initially was involved mostly in fomenting sectarian violence. Its adherents participated in fairly rudimentary attacks involving clubs, machetes and small arms. By late 2010, the group had added Molotov cocktails and simple improvised explosive devices to its tactical repertoire, as reflected by the series of small bombing attacks against Christian targets in Jos on Christmas Eve in 2010.

Boko Haram also conducted a number of armed assaults and attacks in 2011. The Improvised Explosive Devices (IEDs) involved in these attacks were small devices either thrown from motorcycles or left at the attack location. On June 16, Boko Haram made a huge detonation of its first suicide Vehicle borne improvised Explosive Device (VBIED). The attack was directed against the police headquarters in Abuja. While it proved largely ineffective, security kept the vehicle in a parking lot away from the targeted building the attack nonetheless represented a significant tactical development in that it demonstrated that Boko Haram had mastered a completely new aspect of terrorist tradecraft. Employing a suicide VBIED is a far cry from throwing a few sticks of dynamite with a piece of time fuse at a police station or leaving a small IED with a crude timer outside a church. The VBIED was also quite sizable; it destroyed some 40 vehicles in the parking lot. On August 26, Boko Haram conducted a second suicide VBIED attack in Abuja; this time attacked a U.N. compound. This attack proved far more successful than the June attack against the police headquarters. The VBIED driver managed to enter the compound by ramming an exit gate, then maneuvering his vehicle into a parking garage before detonating it. The attack also stands out in that the U.N. compound was located in the diplomatic district of Abuja, where numerous high-profile facilities are located, demonstrating that Boko Haram possessed the ability to spot a soft target amid harder targets like foreign embassies and government buildings. The group's preoperational surveillance efforts also permitted it to accurately identify a security weakness - the exit gate — which it then successfully exploited. This attack was Boko Haram's first attack against a transnational target rather than against a government or sectarian target. Unless the president soon presents a plan of action, Nigerians and foreign investors may lose confidence in his government's ability to deal with Boko Haram's following. It has no clear structure or evident chain of command. Poverty in the area has helped drive young men into the arms of radical Islam. Fervent religious extremism has encouraged people to assail the government. The security services' heavy-handed tactics in trying to quash the violence with random arrests, killings and disappearances have fuelled the discontent. There is the possibility of al-Qaeda having a strong hold in Nigeria if Boko Haram is not tackled early enough.

\section{Kidnapping}

Kidnapping can be defined as the taking away of a person against the person's will, usually for ransom or in furtherance of another crime, is becoming everyone's nightmare in our nation. Daily, we read frightening stories of people being abducted as they go about their daily business. In 2003, around the time when kidnapping became popular in the Niger Delta, the usual victims were foreign nationals working in the oil companies and the culprits were the oil militants demanding control of the natural resources in the oil rich region. Shell Nigeria Exploration and 
Production Company claimed that 133 of its staff were kidnapped between 2006 and 2008. It has since become ubiquitous and commercialised. It has spread from the Niger Delta to virtually all nooks and crannies of the country, with some states of course being hotspots. Similarly victims have changed from being predominantly foreign oil workers to Nigerians, including parents, grandparents, and toddlers and about anyone who has a relative that could be blackmailed into coughing out a ransom. Those behind the recent wave of the despicable act have also changed from being exclusively Niger Delta militants to dodgy elements from different walks of life armed robbers, unemployed, professional 419ers.

There is no doubt that Nigeria is today one of the major kidnapping capitals of the world. This has obvious implications for investments, the country's development path and even the quality of governance. In 2010, Anambra, Rivers, Edo, Akwa Ibom, Delta, Abia and Imo states had become hot spots for kidnapping in Nigeria.

" The phenomenon of kidnapping in Nigeria has taken an alarming and disconcerting dimension which tends to threaten the substratum of our national security," a former Inspector general of Police, Mr Ogbonnaya Onovo, said in August 2010. In 2010, the Nigerian Police claimed that it has arrested over 400 kidnappers. At least six hundred suspected kidnappers arrested in various parts of the southeast are reportedly being detained in different police cells in the zone."Owing to perceived economic marginalization, militant agitations gave rise to kidnapping in the Niger Delta," said John Uwaya, a Security and Investigations researcher. "After the militants embraced the federal government's amnesty, political thugs who appear to have been used and dumped by do or die politicians picked up the vice and by the day it appears the army of unemployed youths are further swelling their ranks." Law enforcement agencies continue to grapple with the threat to security in the country. Military intervention has so far not been able to curb the growing menace. The Senate passed a bill which stipulates capital punishment for acts of terrorism, under which kidnapping is included.

\section{Illegal Arms Importation}

The country just turned into an armory over night; a re-enforcement ground of a sort. Barely after the Abuja bomb blast which almost led to political castration of certain individuals among the political class, came a shocking situation at the Apapa port in Lagos. Shortly after, the alarm raised by experts over the intensity of illegal importation of arms and ammunition into the country through the sea ports and borders eventually came to manifestation on Tuesday, October 26, 2010, when men of the Nigeria Customs Service (NCS) and the State Security Service (SSS) discovered 13 container loads of arms and ammunition at the Apapa Wharf Ports Complex in Lagos. The detection was made barely two weeks after a consignment of electronic equipment suspected to contain toxic materials was confiscated at the same port. The vessel that brought in the shipment, however, departed from the port. There were speculations from many quarters that those arms were meant for the 2011 general elections. The widespread availability of small arms and light weapons has helped stoke a decade of unrest in the region that produces nearly all of Nigeria's oil, which is rife with hostage-taking, attacks on oil installations and fighting among rival militias. According to Babafemi Ojudu, a researcher who has investigated the small-arms trade in the country, the Niger Delta has long had easy access to small weapons, but growing 
violence and militarisation in the region has been a boost to the trade in recent years. He said smugglers operating out of Equatorial Guinea, Gabon, Cameroon and Nigeria have always coordinated the trade. "Using fast boats, these smugglers cruise to ships in the high seas and obtain guns, the origins of which may be as far as Eastern Europe and Asia," said Ojudu.

We have witnessed the illegal circulation of small arms by smugglers across the land borders of neighbouring countries of Benin, Niger, Chad and Cameroon, has had an impact not only on widespread armed banditry but also on ethnic and religious violence that have claimed lives. Another key arms-smuggling route into Nigeria is the Lagos-Benin coastal axis extending across West Africa as far as Liberia and Sierra Leone. In November 2003, customs officials intercepted a lorry carrying 170,000 rounds of ammunition concealed in a cargo of charcoal that had crossed the border from Benin into Nigeria. It was pronounced one of the biggest seizures in Nigeria.

An equally worrisome source of weapons is Nigeria's northern borders with Chad and Niger. Nigerian security agencies say remnants of rebel wars in both countries have drifted southwards with their weapons into Nigeria over the past decade. Operating in large bands of 30 to 50 armed men, they engage in banditry on highways in northeast and central Nigeria. "They are even hired as mercenaries to fight in land disputes or in communal or religious conflicts in the area," said a Nigerian army intelligence official. Many experts say Nigeria's problems with small arms and light weapons date back to the country's 1967-1970 civil wars, during which the southeast made a failed attempt to secede. "Many of the small arms used in that war, especially on the rebel Biafran side, weren't mopped up at the end of hostilities," said Patrick Oraeke, a security consultant. He said the war created a generation of people who had trained in the use of weapons but were not under the discipline and control of any of the armed forces. As a result, they easily resorted to banditry. There is evidence, too, that arms flowed into Nigeria as a result of the civil wars in Sierra Leone and Liberia, where Nigerian soldiers were involved in peacekeeping missions. Both smugglers and soldiers brought in weapons from those conflicts. In one known case, Sergeant Barnabas Mshelia a soldier testifying as a prosecution witness in one of several political-assassination cases recorded under the late military ruler General Sani Abacha, told a court he was given an AK-47 rifle brought in from Liberia by his superiors to use in the assassination attempt on a perceived opponent of Abacha. The would-be assassins had reasoned that the weapon would be harder to trace since it was not registered.

The availability and wide circulation of these arms pose the greatest danger to peace and security, especially in our country. These weapons if gotten on the wrong hands, undermined stability, social peace and security and have wrought devastation on our economy.

\section{Power Generation}

For every Nigerian especially in the business community, the threat posed by inadequate power generation is seen as the most important national security threat to be tackled by government. Various articles in the media have posited that, once power generation is constant, joblessness and crime will reduce. There will be rapid economic growth and Nigeria will be able to achieve some of the aspirations contained in the vision 2020 document. The President has pledged on many occasions that the issue of power generation will be given number one priority and that very soon gradual improvement will be seen in our power situation. The problem posed by 
inadequate power generation to National security is visible in many years, in the shutdown of companies, relocation of factories to other countries, increase in criminal activities, loss of revenue etc.

\section{Oil Bunkering}

Oil bunkering is effectively Nigeria's most profitable illegal private business in the petroleum industry. 'Illegal oil bunkering' is therefore a euphemism for theft of oil (Human Rights Watch 2003), which involves tapping crude oil directly from the pipelines. Illegal oil bunkering is a hazardous business that is very pervasive in the creeks of the Niger Delta where oil pipelines criss-cross the region like a grid. Thieves construct a temporary enclosure around a small section of underwater pipe. Water is then pumped out from the enclosure and a hole is drilled into the steel casting of the pipe through which the crude passes. The hole is fitted with a pipe and control valve. The creek water is allowed to flow back and fill the enclosure so that the set-up is underwater and therefore hidden from oil company inspectors (Junger 2007:56). When crude oil is being pumped through the pipelines, sometimes at a pressure of 600 pounds per square inch, the bunkers are able to fill up to a 1000 metric tonne barge in a matter of hours. The barge is then moved offshore to a transport ship and the oil is sold on the high seas. Oil bunkering has become a sophisticated operation that does not require the co-operation of oil company staff to operate equipment at wellheads or allow access (though there are reports that some are indeed involved in the theft).

The bunkerers now tap directly into pipelines at a site removed from oil company facilities, and connect the pipes to barges that are hidden in small creeks under cover of mangrove forests (Human Rights Watch, 2003). It is estimated that over 10 per cent of the oil exported from Nigeria every year has actually been bunkered. Because oil bunkering is a huge and lucrative business in Nigeria, with a whole demand and supply chain, a network of actors have emerged to sustain the activity. These include, but are not limited to, cult leaders, politicians, serving and retired security agents, shipping lines, international oil dealers, and youths conscripted by the cult leaders to puncture the pipelines as well as provide security during the transportation of the oil to the market. Two examples serve to illustrate the magnitude of the operation: in August 2003 the navy announced that it had arrested ten foreigners (among them Senegalese, Burkinabe, Togolese, Ivoirians and Beninois) and a number of Nigerians for involvement in oil smuggling, and seized four ships; in late October, several more ships were impounded, with a reported combined cargo of oil worth several hundred million dollars (Human Rights Watch 2003). Even then, up till 2002, the navy could only intercept and arrest barges (Ikelegbe2005:223). The intensification of naval patrols and the intervention of the Nigerian navy since 2003 have had some positive effects on the illegal bunkering. In 2003 the Nigerian oil industry was losing an average of 160000 barrels of crude oil per day to criminal elements. This figure has been brought down to less than 30000 barrels per day (according to NNPC figures) or 10000 barrels (according to the Nigerian navy) (Egua 2006:1, 7). Meanwhile, Nigeria loses as much as N10.75 billion every month to criminal syndicates of crude oil and refined petroleum products thieves operating actively in the swamps of the Niger Delta, and offshore, in Nigeria's territorial waters, 
according to sources at the Ministry of Defence. It gives the impression that Nigeria is a country incapable of securing its vital natural resources. Oil bunkering will continue to be a security threat.

\section{Corruption}

The problem of corruption as captured in the epigraph and alluded to by many commentators on the subject has always been with us. It is no less a person than Nwabueze quoting Ayandele, who traced the malaise as having found root in governance at the dawn of independence of African States from their colonial masters. He comments:

..Later day ruling elite who altogether careless or disdainful of the interests of the masses, were enabled to achieve their dream of stepping into privileged positions hitherto the white man's exclusive preserve. Thus the ambition and the desire to exploit the people by means of official corruption in all its variegated forms became implanted in the mentality and psyche of the African ruling class. Corruption manifests a want of patriotism and a sense of service to the people.

The decisive thinker continues:

The effect of this on civil servants is that service as a hard working civil servant has come to be viewed as unrewarding to him; it now seems foolish to remain a poor, dutiful and honest civil servant when his political bosses are busy openly amassing wealth unabashed by any code of conduct.

Not done yet, he says further that:

Elitism in Africa has enthroned money as the accepted measure of success, as a criterion of honour or worthiness, as the determinant of social values, indeed as every object of existence. All relationship in the society...practically everything, has come to be measured in terms of money and money related values.

He then opines that happenings in African States are just like in the Plato's The Republic whereby "in proportion as riches and rich men are honoured in the state" whilst "virtue and the virtuous are dishonoured". Corruption is a wrongdoing by those in a special position of trust. The term is commonly applied to self-benefiting conduct by public officials and others dedicated to public service. It means dishonesty for personal gain; meaning dishonest exploitation of power for personal or selfish gain. Corruption could also mean depravity or extreme immorality. Transparency International (TI) defines corruption as the misuse of entrusted power for private gains .TI went further to differentiate between " according to the rule" Corruption and "against the rule" Corruption. Facilitation payments where a bribe is paid to receive preferential treatment for something that the bribe receiver is required to do by law, constitute the former. The latter on the other hand is a bribe paid to obtain services; the bribe receiver is prohibited from providing. Nuhu Ribadu sees corruption as the reason why social infrastructures are nonexistent or dilapidated; it is the reasons why values are upside down and responsible for the nation's underdevelopment.

Although corruption has been consistently confronted by successive governments, particularly in recent times with the establishment of such anti-corruption outfits as the Independent Corrupt 
Practices Commission (ICPC) and the Economic and Financial Crimes Commission (EFCC), the menace has remained disturbingly resilient. The cankerworm of corruption has eaten deep into the fabric of our society and is now encroaching on our collective values.

No formal or informal institution in this country has been spared the affliction of corruption, including the institution of the family that until now was a fortress of control and inculcation of ethical values into our children. Now, some parents encourage it by supporting their children in examination malpractices, while entire communities often approve the garlanding of ostensibly corrupt but rich current and former public officials whose source of wealth are at best, be questionable. The challenge of corruption is, therefore, at the root of our underdevelopment. It has become so pervasive that many essential public projects for which vast sums of money have been paid to the concerned contractors have either been abandoned or remained uncompleted. And where such public projects have been completed, their costs are always higher in comparison with the costs of similar projects in other countries.

Corruption is common in third world countries more than the advance countries because of the weak institutions. It is a serious security threat.

\section{Conclusion}

The response of the Nigerian State to the threats identified in this article depends on the degree of threat perception as understood by decision makers. At all times, the overall national interest of providing security and protecting the interest of the Nigerian public should suffice to guide decision makers. There are potential threats that should be addressed as soon as identified. Both internal and external threats are equally dangerous and must be prioritized. Oil bunkering in the Niger Delta and Kidnapping in South East of the Country as well as religious fundamentalism and the threat from Boko Haram are immediate threats which should be accorded high priority.

Military engagement is not adequate; the state must engage in covert intelligence gathering and open up channels of communication with the disgruntled and disenchanted parties. However the immediate objective of stopping the physical violence on the populace remains a top priority. However the citizenry themselves also have some roles to play by being law abiding. A growing economy helpful to local entrepreneurship and attractive to foreign investors remains impossible while the free flow of people, goods, and ideas is restricted due to threats to security.

\section{Reference}

Abayomi, F.,D., Matswamgbe, M., Onwurah,U., and Okpewho,L., (2005). Report of F.K Mohammed (Eds), Oiling Violence: The Proliferation of Small Arms and Light Weapons in the Niger Delta.Lagos: Frankard Publishers.

Abubakar, A.2006. Pipeline Vandalization Causes Fuel Shortages at Northern Depots. Weekly Trust, 713 October 2006.

Adeline, C., (1996). The War against the poor: the Underclass and Antipoverty Policy. New York: Basic Books. 
Adeniyi, O.2007 "Playing with Fire” (1).Thisday, January 18, p.12.

Adibe, J.2010.Pervasive kidnapping in Nigeria: Symptom of a failing State? Available at http;//www.hollerafrica.com/showarticles.php?artld=304\& catld=[accessed 21 October 2011]

Africanoiljournal.com (2007). Union calls for a meeting to investigate Nigeriapipeline disaster Available at http://www.africanoiljournal.com/01-03-2007\%20union calls for-a-meeting-t0investigate\%20nigeria\%pipeline\%20disaster.htm[accessed 15 September 2011].

Ahmed,A.(2007).Pipeline Sabotage in Nigeria and Oil Pollution Damage out of context .Avaliable at http://www.amanaonline.com/art-pipeline.htm/accessed 21 October 2011]

Al-Mashat,A.M.(1985).National Security in the Third World. Boulder Colo: Westview Press.

Amanze-Nwachukwu, C.2007.”Boxing Day Tragedy: It is Time for Solution”.Thisday, January 2, 2007 p.13.

Amanze-Nwachukwu, C.2007 “Oil Firms Face A Bleak” Thisday, February 4, 2007 p.14

Analysis Nigeria's $\quad$ growing Avaliable at at http://www.234next.com/csp/cms/sites/Next/Home/5682117./story.csp[accessed $21 \quad$ October $2011]$

Andersen,M. and Taylor,H. (2005) Sociology: The Essentials, Third Edition,Belmont,Carlifonia :Thomson Wadsworth.

Ayoola, G and Taylor, M Nigeria: Voice of the Poor, World Development Report (Consultation with the poor) 2000/2001

Balogun,T.(2003)."Current State of Security in the Country and police preparedness to the forth Coming 2003 Elections" Paper presented at an All Stakeholders Conference, Organized by the Head of Service of the Federation in Abuja.

Bamidele, Y.2010. “Police Intercept Weapons in Oyo” Daily Trust, $9^{\text {th }}$ November 2010.

Bammel,H.(2006) “Foreword”,In Friederich Ebert Stiftung:Report On Violent Conflicts in Nigeria 2004-2005,Lagos:Friederich Ebert Stifung (FES) and Peace and Development Project (PEDEP).

Bassey,C.(2001) Defence and Security: An African perspective. Paper Presented at the interOrganisational Seminar on Conflict Research and Techniques, Abuja, 14 June, Abuja: Institute for peace and Conflict Resolution.

Bello, O.2007.Frequent Pipeline Vandalization Cost Businessday, 19th February 2007 p.10. 
Brume,F.(2006) Oil Vandalization in the Niger Delta: The Way Out .Available at http://www.nigerdeltacongress.com/articles/oil.htm [accessed 21 October 2011]

Bello, A.2010.70\% of illegal Arms in West Africa are in Nigeria NATFORCE Boss Daily Trust, 9th November 2010, p.29.

Chiedozie, I. (2007).Niger Delta: Why we haven't taken military action-Obasanjo.Avaliable at http://punchng.com/Articl.aspx?theartic= Art200702091535820 [accessed 9 March 2011]

DFID: Background Briefing; Poverty Reduction Strategies, London 2001.

Dokubo, C. (2010).The Proliferation of Small Arms and Light Weapons in West Africa: Implications for sub regional Security “In O.Eze, C.Anigbo and C.Dokunbo (Eds) Nigeria's Security Interest in Africa, Lagos: Nigeria Institute of International Affairs

Duquet,N.(2011) Swamped with weapons :The Proliferation of Illicit Small Arms and Light Weapons in the Niger Delta in C. Obi and S.Rustad (Eds) Oil and Insurgency in the Niger Delta: Managing the Complex Politics of Petroviolence .London and New York: Zed Books.

Economic and Financial Crimes Commission (EFCC) (2007).Oil Bunkering: Fleeing Traditional Ruler arrested 28 August.Avaliable at

http://www.efccnigeria.org/index.php?option=com_conte\&task=viewid=410\&1temid=68/accessed $1^{\text {st }}$ September 2011]

Egua, H.2006."Anti-bunkering operations Save Nigeria N1.1bn daily, says Navy”Businessday, 28 November 2006, p.10.

Falk, R. (1975). A Study of Future Worlds. New York: Free Press.

Federal Republic of Nigeria 1990 Laws of the Federation of Nigeria .Lagos: Federal Government Press.

Federal Republic of Nigeria 1999. Constitution.Lagos: Federal Government press.

Federal Republic of Nigeria 2006. National Defence Policy .Abuja: Federal Government Press.

Godwin,A and Ezeobi,O .2007.”Blackout May Linger till May “.The Punch, 7 March, p.1.

Gusau,I 2010 “Jos Bound Men with 27 Guns Arrested”. Daily Trust, 17 August, p.1.

Hartmann, F (1983) The Relations of Nations. New York: Macmillan.

Human Rights Watch. (2002).The Niger Delta: No democratic dividend. Short Report. New York: Human Rights Watch, October 2002. 
Human Rights Watch (2003) Available at http://www.hrw.org/reports/nigeria1103/5.htm

Ikelegbe, A. (2005) The Economy of conflict in the Oil rich Niger Delta Region of Nigeria. Nordic Journal of African Studies 14 (2):208-234.

Ikokwu, C.2007.”Nigeria: Oil theft Costs Nigeria \$14 billon yearly”.Thisday, 28 August 2007 p.20.

IMF/World Bank: Poverty Reduction Strategy Papers -Optional Issues (Discussion) Dec 1999 Washington DC: World Bank

Imobighe, T.A (1990)"Doctrine for and Threats to Internal Security" in A.E Ekoko and M.A Vogt (Eds) Nigerian Defence Policy: Issues and Problems, Lagos: Malt House Press.

Junger, S.2007. “Blood Oil on Nigeria’s Delta Creeks”. The Guardian, January 14, 2007 p.12.

Kingsley, N.2010."Civil War 17,000 Unexploded Bombs Recovered in South East”, Thisday, 4th November 2010 p.12.

McNamara, R.S (1968).The Essence of Security .New York: Harper\& Row.

Mumuni, M .and Oyekunle.J 2007.”Generals behind bunkering”Sunday Sun, June 10, 2007, p.10.

Nwolise, OBC. (1988) "Nigeria's Defence and Security System Today" in U.Uleaz (Ed) Nigeria The 25 years Ibadan: Heinman.

Ochoche, S.A (1997) "Changing Concept of International Peace and Security” in Chris A. Garuba, $(E d)$; International Peace and Security: The Nigerian Contribution. Lagos, Gabumo press.

Odimegwu, M. (2011)"Taming the Monster of Post-elections Violence in Nigeria”, The Punch, April $30^{\text {th }}, 2011$.

Ohia, P.2010."Gambia cuts Ties with Iran over Nigeria Arms Seizure”.Thisday $23^{\text {rd }}$ November, 2010.p.12.

Olagoke, A.2007.” Militants free 24 Filipino hostages". The Guardian, 1st February 2007. P.10

Okodolor, C. (2004).National Security and Foreign policy: Towards A Review of Nigeria's AfroCentric policy. Nigerian Forum, 25(7-8):209-219, July-August.

Olugbode, M.2010."Mother of Seven Arrested with AKA47s”Thisday 10 November p.10.

Omonobi, K.2007."Navy arrest 236 ships for illegal bunkering, other vices in three years", Vanguard, 8th September 2007 p. 16. 
Onuoha, F.C. (2009).Corruption and National Security: The three Gap-Theses and the Nigerian Experience .Nigeria Journal of Economic and Financial Crimes (12), pp1-13.

Onuoha, F.C. (2007).Ethnic militias and National Security: The Transformation of Conflicts in the Niger Delta .Paper presented at the National Conference on Nigeria beyond 2007: Issues, perspectives and Challenges. Faculty of Business and Social Sciences, University of IIlorin, 27 and 28 February.

Onuoha, F.C (2007).Poverty, Pipeline Vandalization/explosion and Human Security: Integrating Disaster Management into Poverty Reduction in Nigeria. African Security Review, 16(2):94108.

Onuoha, F.C. (2007). Why the poor pay with their lives: Oil Pipeline Vandalization, fire Disaster and Human Security in Nigeria. The Journal of Disaster Studies, Policy and Management.

Onuoha, F.C. (2010).The Islamist Challenge: Nigeria's Boko Haram Crisis Explained African Security Review, 19(2), pp54-67

Onuoha, F.C (2011).Nigeria's Vulnerability to Terrorism: The Imperative of A Counter Religious Extremism and Terrorism (CONREST Strategy peace and Conflict Monitor, Available at: http://monitor.upeace.org/ innerorpg.efm?idarticle=772[Accessed on 23 February 2011]

Responding to Terrorism in Nigeria. Available at://www.234next.com[Accessed 21 October 2011]

Special Committee on the Review of petroleum product Supply and Distribution. (2000) Report. Abuja: Federal Government Press.

Stephen, W. (1992) "Security, Modernity, and Ecology: The Dilemmas of Post-cold war Security Discourse "Alternatives, Vol.17.

Thomas, C. (1987).In search of Security: The Third World in International Relations Brighton: Lynne Rienner.

Tyoden, S.G. (2005). “State and Security in Nigeria's Fourth Republic”.In A.T Gana and Y.B Omelle (Eds),Democratic Rebirth in Nigeria.vol 1,1999-2003.Abuja:AFRIGOV.

Prins, G. (1984).The Paradox Security In G.Prins (ed),The Choice: Nuclear Weapons Versus Security. London: Windus.

Wolfers.A. (1962). Discord and Collaboration. Baltimore: John Hopkins University Press. 